\title{
Pertumbuhan Padi Gogo yang dipengaruhi oleh Aplikasi Pupuk Hayati dan Pupuk NPK pada Andisols
}

\author{
Betty Natalie Fitriatin ${ }^{1)}$, Robi Silpanus²), Tien Turmuktini'2), Emma Trinurani Sofyan'1), dan \\ Anni Yuniarti1) \\ 1)Departemen Ilmu Tanah dan Sumberdaya Lahan, Fakultas Pertanian Universitas Padjadjaran \\ Jl. Raya Bandung Sumedang Km 21 Jatinangor \\ 2) Fakultas Pertanian Universitas Winayamukti, Jl. Raya Bandung Sumedang No.29, Tanjungsari
}

Korespondensi: betty.natalie@unpad.ac.id

\begin{abstract}
Intensive inorganic may lead to land degradation, and can be amended with the aid of biofertilizers. This study was conducted to investigate the application of biofertilizer (phosphatesolubilizing mircrobes and nitrogen-fixing bacteria) and inorganic fertilizers on the growth of upland rice on Andisols. Randomized Block Design (RBD) in factorial pattern were used as experimental design, which consisted of two factors with three replications. The first factor consisted of biofertilizer addition dosages: without biofertilizer, biofertilizer consortia 1 (Pseudomonas mallei, P. cepaceae, Aspergillus niger and Penicillium sp., Azotobacter chroococum, Azospirillum sp.), biofertilizer consortia 2 (Azotobacter choroococum, A. viilandii, Azospirillum, Pseudomonas cepaceae, Penicillium and Acitenobacter) and the mixture of biofertizer consortia 1 and 2. The second factor were Nitrogen-Phosphate-Potassium fertilizer which consisted of four levels $1100 \%$, 75\%, 50\% and 25\% of The Indonesian Ministry of Agriculture recommended dosage). The results showed that the application of biofertilizer consortia increased the growth of upland rice and fertilizer efficiency on Andisols.
\end{abstract}

Keywords : Andisols, biofertilizers, NPK fertilizers, upland rice

\section{PENDAHULUAN}

Andisol merupakan tanah yang memiliki potensi penting sebagai media pertumbuhan tanaman karena memiliki kandungan bahan organik yang tinggi (Tan, 2008). Namun Andisol memiliki kendala diantaranya yaitu $\mathrm{pH}$ tanah yang masam serta ketersediaan $\mathrm{P}$ yang rendah. Rendahnya ketersediaan $\mathrm{P}$ ini disebabkan oleh terikatnya unsur $P$ secara kuat pada koloid tanah serta adanya retensi $\mathrm{P}$ yang tinggi yaitu $>80 \%$ (Hardjowigeno, 2003).

Retensi P merupakan salah satu permasalahan penting, terutama pada tanah kering masam dengan tekstur liat yang mengandung banyak oksida $\mathrm{Al}$ dan $\mathrm{Fe}$ (Tan, 2008). Tingginya retensi $\mathrm{P}$ ini mengakibatkan penggunaan pupuk $\mathrm{P}$ menjadi tidak efisien. Untuk mengatasi permasalahan $\mathrm{P}$ pada Andisol, diperlukan penanganan secara berkelanjutan melalui pemanfaatan mikrob tanah yang berperan dalam transformasi P.
Upaya meningkatkan produktivitas lahan secara berkelanjutan dapat dilakukan dengan aplikasi pupuk hayati (biofertilizers) dan agen biologis (biological agent) serta amelioran organik. Pupuk hayati adalah inokulan berbahan aktif organisme hidup dalam bentuk cair atau padat yang memiliki kemampuan untuk memobilisasi, memfasilitasi dan meningkatkan ketersediaan hara tidak tersedia menjadi bentuk tersedia melalui proses biologis (Rao, 1994).

Kelompok pupuk hayati yang sangat potensial untuk diaplikasikan pasa sistem pertanian terpadu dan berkelanjutan, antara lain meliputi: penambat $\mathrm{N}$, mikroba pelarut $\mathrm{P}$ dan $\mathrm{K}$, mikroba tanah penghasil fitohormon (plant growth promoting rhizobacteria), mikroba perombak bahan organik (decomposer) dan mikroba yang berperan sebagai agen hayati (Singh dan Purohit, 2011). Pupuk hayati yang sangat berperan dalam peningkatan status hara tanah sub optimal antara 
lain mikroorganisme pelarut $\mathrm{P}$ dan bakteri pemfiksasi N.

Kontribusi pupuk hayati di Indonesia masih relatif rendah dibandingkan potensinya. Bakteri penambat $\mathrm{N}_{2}$ (simbiotik dan nonsimbiotik) dapat dimanfaatkan untuk mensuplai kebutuhan $\mathrm{N}$ tanaman hingga $75 \%$. Fitriatin, dkk. (2014) menyatakan bahwa mikroba pelarut $\mathrm{P}$ berperan penting dalam meningkatkan efisiensi pupuk P hingga 50\% untuk tanaman jagung pada Ultisols. Lebih lanjut hasil penelitian Fitriatin, dkk (2018) menunjukkan bahwa aplikasi pupuk hayati berupa konsorsium Pseudomonas mallei, P.cepaceae, A.niger, Penicillium sp, Azotobacer chroococum, Azospirilum sp. yang dikombinasikan dengan asam humat mampu meningkatkan hasil padi hingga 8,93 tha- ${ }^{-1}$ dan mengurangi dosis pupuk NPK hingga $50 \%$.

Keefektifan pupuk hayati dalam mendukung pertumbuhan dan perkembangan tanaman bergantung pada (1) kualitas inokulan (isolat) baik sebagai inokukan tunggal maupun inokulan majemuk (konsorsium pupuk hayati), (2) kualitas dan komposisi bahan pembawa (carrier) berkaitan langsung efektivitas dan viabilitas bahan aktif, (3) ketersediaan bahan organik tanah berkaitan langsung dengan ketersediaan energi bagi pupuk hayati yang bersifat heterotrof, (4) dosis dan teknik aplikasi (Simarmata, dkk. 2012).

Tujuan penelitian yang dilakukan adalah menentukan konsorsium pupuk hayati yang terbaik untuk meningkatkan optimasi formula pupuk hayati berupa konsorsium mikroba pelarut $\mathrm{P}$ dan bakteri pemfiksasi $\mathrm{N}$ yang unggul dan bersinergi dalam memperbaiki status hara tanah sub optimal dan peningkatan produksi padi.

\section{METODOLOGI}

Percobaan dilaksanakan di kebun percobaan Fakultas Pertanian Universitas Winaya Mukti Sumedang, dengan ketinggian tempat $856 \mathrm{~m}$ dpl. Penelitian dilaksanakan pada bulan Mei sampai Oktober 2018.
Percobaan dilakukan dalam pot dengan menggunakan polibeg berukuran $15 \mathrm{~kg}$. Rancangan percobaan menggunakan rancangan acak kelompok (RAK) faktorial yang terdiri dari dua faktor dengan tiga ulangan.

Faktor pertama adalah pupuk hayati yang terdiri dari empat taraf:

- Tanpa pupuk hayati

- Konsorsium 1 (Pseudomonas mallei, P.cepaceae, A.niger, Penicillium sp, Azotobacer chroococum, Azospirilum sp.)

- Konsorsium 2 (P. cepaceae, Azotobacer chroococum, A. vilandii, Azospirilum, Penicillium, Acitenobacater)

- Campuran konsorsium $1+2$.

Faktor kedua adalah dosis $\mathrm{N}, \mathrm{P}, \mathrm{K}$ yang terdiri dari empat taraf, yaitu : $100 \%, 75 \%, 50 \%$, dan $25 \%$ dosis rekomendasi. Dosis pupuk

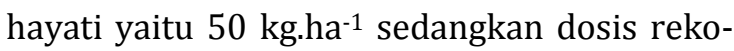
mendasi pupuk NPK yaitu Urea 250 kg.ha-1, SP-36 100 kg.ha-1 $^{-1}$ KCl 100 kg.ha $^{-1}$.

Tanah yang digunakan sebagai media tanam yaitu Andisols asal Tanjungsari. Benih padi gogo mengunakan varietas Situ Bagendit. Pengamatan terhadap pertumbuhan tanaman yaitu tinggi tanaman dan jumlah anakan yang diamati secara periodik sampai fase vegetatif akhir.

Perbanyakan isolat bakteri pelarut fosfat dan bakteri pemfiksasi nitrogen menggunakan nutrient broth (NB) sedangkan jamur pelarut fosfat menggunakan potato dextrose broth (PDB). Masing-masing biakan murni dari setiap isolat dimasukan ke dalam media perbanyakan sebanyak $10 \%$ dari volume media selanjutnya dikocok dengan shaker 112 rpm selama 3 hari.

Bakteri pelarut fosfat dan jamur pelarut fosfat serta bakteri pemfikasi $\mathrm{N}$ dihitung terlebih dahulu populasinya dengan metode Total Plate Count (TPC) sebelum dimasukkan ke dalam bahan pembawa yaitu campuran gambut dan kompos perbandingan 1:1 sebanyak $10 \%$ volume berat bahan pembawanya. 


\section{HASIL DAN PEMBAHASAN}

\subsection{Tinggi Tanaman}

Berdasarkan hasil percobaan aplikasi konsorsium pupuk hayati nyata meningkatkan tinggi tanaman padi gogo pada tanah Andisols pada pengamatan 7-28 hari setelah tanam
(Tabel 1). Secara umum konsorsium pupuk hayati 1 (Pseudomonas mallei, P.cepaceae, A.niger, Penicillium sp, Azotobacer chroococum, Azospirilum sp.) memberikan pertumbuhan lebih baik dibandingkan dengan konsorsium 2 ataupun gabungan konsorsium 1 dan 2.

Tabel 1 Tinggi tanaman padi gogo pada tanah Andisols (7-28 hari setelah tanam)

\begin{tabular}{lrrrr}
\hline \multicolumn{1}{c}{ Perlakuan } & 7 HST $(\mathrm{cm})$ & 14 HST $(\mathrm{cm})$ & $21 \mathrm{HST}(\mathrm{cm})$ & $28 \mathrm{HST}(\mathrm{cm})$ \\
\hline Pupuk hayati konsorsium & & & & \\
- tanpa pupuk hayati & $11,82 \mathrm{a}$ & $15,22 \mathrm{a}$ & $20,47 \mathrm{a}$ & $22,83 \mathrm{a}$ \\
- konsorsium 1 & $11,84 \mathrm{a}$ & $20,42 \mathrm{~b}$ & $25,82 \mathrm{~b}$ & $29,30 \mathrm{~b}$ \\
- konsorsium 2 & $12,95 \mathrm{~b}$ & $18,51 \mathrm{~b}$ & $24,57 \mathrm{~b}$ & $27,63 \mathrm{~b}$ \\
- konsorsium 1+2 & $13,11 \mathrm{~b}$ & $17,74 \mathrm{~b}$ & $24,06 \mathrm{~b}$ & $27,03 \mathrm{~b}$ \\
\hline Dosis Pupuk NPK & & & & \\
- 100\% & $12,09 \mathrm{a}$ & $17,43 \mathrm{a}$ & $23,53 \mathrm{a}$ & $27,12 \mathrm{a}$ \\
$-75 \%$ & $12,45 \mathrm{a}$ & $18,10 \mathrm{a}$ & $23,49 \mathrm{a}$ & $26,66 \mathrm{a}$ \\
$-50 \%$ & $12,71 \mathrm{a}$ & $18,26 \mathrm{a}$ & $24,14 \mathrm{a}$ & $26,39 \mathrm{a}$ \\
$-25 \%$ & $12,48 \mathrm{a}$ & $18,10 \mathrm{a}$ & $23,76 \mathrm{a}$ & $26,62 \mathrm{a}$ \\
\hline
\end{tabular}

Keterangan : Nilai rata-rata yang diikuti dengan huruf yang sama tidak berbeda nyata menurut Uji Jarak Berganda Duncan pada taraf 5\%.

Aplikasi berbagai dosis pupuk NPK tidak mempengaruhi terhadap tinggi tanaman. Hal ini menunjukkan bahwa aplikasi pupuk hayati mampu berkonstribusi terhadap efisiensi pupuk anorganik. Hal ini terlihat dari pengaruh pengurangan dosis pupuk NPK tidak mempengaruhi terhadap tinggi tanaman pada umur 7-28 HST.

Hasil analisis statistik menunjukkan bahwa terdapat interaksi antara pupuk hayati dan pupuk NPK terhadap tinggi tanaman pada umur 35 HST. Secara umum aplikasi pupuk hayati mampu meningkatkan pertumbuhan tanaman padi gogo (Tabel 2). Aplikasi pupuk NPK pada berbagai taraf pupuk hayati memberikan pengaruh yang nyata. Biswakarma et al. (2018) menyatakan bahwa kombinasi pupuk hayati BPF dan pupuk NPK mampu meningkatkan tinggi tanaman padi pada umur 30 hari setelah tanam.

Tabel 2 Pengaruh interaksi antara aplikasi pupuk hayati dan NPK terhadap tinggi tanaman pada 35 HST

\begin{tabular}{|c|c|c|c|c|}
\hline \multirow{2}{*}{ Perlakuan } & \multicolumn{4}{|c|}{ Rerata tinggi tanaman umur 35 HST $(\mathrm{cm})$} \\
\hline & NPK $100 \%$ & NPK $75 \%$ & NPK $50 \%$ & NPK $25 \%$ \\
\hline \multirow[t]{2}{*}{ Tanpa pupuk hayati } & $24,06 \mathrm{a}$ & $22,82 \mathrm{a}$ & $27,17 \mathrm{a}$ & $27,29 \mathrm{a}$ \\
\hline & A & A & B & B \\
\hline \multirow[t]{2}{*}{ Konsorsium 1} & $37,47 \mathrm{~b}$ & $36,72 \mathrm{~b}$ & $35,40 \mathrm{~b}$ & $34,04 \mathrm{~b}$ \\
\hline & B & B & A & A \\
\hline \multirow[t]{2}{*}{ Konsorsium 2} & $29,45 \mathrm{~b}$ & $31,14 \mathrm{~b}$ & $29,16 \mathrm{~b}$ & $31,02 \mathrm{~b}$ \\
\hline & A & B & A & A \\
\hline \multirow[t]{2}{*}{ Konsorsium $1+2$} & $32,77 \mathrm{~b}$ & $29,14 \mathrm{~b}$ & $29,54 \mathrm{~b}$ & $29,10 \mathrm{~b}$ \\
\hline & B & A & A & A \\
\hline
\end{tabular}


Pengurangan dosis pupuk NPK dari 75\% sampai dengan $25 \%$ yang dikombinasikan dengan aplikasi pupuk hayati konsorsium $1+2$ tidak berpengaruh nyata terhadap tinggi tanaman (Tabel 2). Hal ini menunjukkan bahwa pemberian pupuk hayati mampu meningkatkan efisiensi pemupukan anorganik. Vahed et al. (2012) menyatakan bahwa pupuk hayati BPF mampu meningkatkan pertumbuhan padi sampai dengan $24 \%$ dan mengurangi kebutuhan pupuk $\mathrm{P}$ hingga 50\%. Saba et. al. (2013) melaporkan bahwa aplikasi pupuk hayati $500 \mathrm{~kg} . h a-1^{-1}$ mampu meningkatkan hasil padi sampai dengan 9,23 t.ha-1 dan mengurangi kebutuhan pupuk NPK.

Tabel 3 Pengaruh interaksi antara aplikasi pupuk hayati dan NPK terhadap tinggi tanaman pada 42 HST

\begin{tabular}{lcccc}
\hline \multirow{2}{*}{ Perlakuan } & \multicolumn{4}{c}{ Rerata tinggi tanaman umur 42 HST } \\
\cline { 2 - 5 } & NPK $100 \%$ & NPK $75 \%$ & NPK 50\% & NPK 25\% \\
\hline Tanpa pupuk hayati & $32,83 \mathrm{a}$ & $30,11 \mathrm{a}$ & $38,14 \mathrm{~b}$ & $36,42 \mathrm{a}$ \\
& $\mathrm{B}$ & $\mathrm{A}$ & $\mathrm{B}$ & $\mathrm{B}$ \\
Konsorsium 1 & $40,13 \mathrm{~b}$ & $39,75 \mathrm{~b}$ & $38,15 \mathrm{~b}$ & $37,64 \mathrm{a}$ \\
& $\mathrm{B}$ & $\mathrm{A}$ & $\mathrm{A}$ & $\mathrm{A}$ \\
Konsorsium 2 & $39,09 \mathrm{~b}$ & $39,17 \mathrm{~b}$ & $35,67 \mathrm{a}$ & $36,11 \mathrm{a}$ \\
& $\mathrm{B}$ & $\mathrm{B}$ & $\mathrm{A}$ & $\mathrm{A}$ \\
Konsorsium 1+2 & $40,26 \mathrm{~b}$ & $36,07 \mathrm{~b}$ & $38,24 \mathrm{~b}$ & $35,90 \mathrm{a}$ \\
& $\mathrm{B}$ & $\mathrm{A}$ & $\mathrm{B}$ & $\mathrm{A}$ \\
\hline
\end{tabular}

Keterangan: Angka yang ditandai huruf sama tidak berbeda nyata pada uji jarak berganda Duncan taraf $5 \%$. Huruf kecil dibaca vertikal, huruf besar dibaca horizontal

Berdasarkan Tabel 3 terdapat interaksi antara pupuk hayati dan NPK terhadap tinggi tanaman padi gogo pada umur 42 HST. Pada dosis NPK $75 \%$ dan $100 \%$, aplikasi pupuk hayati nyata meningkatkan tinggi tanaman. Namun, pengurangan dosis NPK sampai $25 \%$ memberikan pengaruh terhadap efektifitas pupuk hayati. Hal ini dikarenakan pada umur tanaman 42 HST, tanaman telah banyak menyerap hara dari tanah sehingga mempengaruhi pertumbuhan dan kinerja mikroba dalam pupuk hayati.

\subsection{Jumlah Anakan}

Pertumbuhan tanaman padi gogo dapat dilihat juga dari banyaknya jumlah anakan. Hasil percobaan menujukkan bahwa aplikasi pupuk hayati mampu mningkatkan jumlah anakan padi gogo pada Andisols. Secara umum konsorsium 2 (Pseudomonas cepaceae, Azotobacer chroococum, A. vilandii, Azospirilum, Penicillium, Acitenobacater) mampu meningkatkan jumlah anakan lebih banyak dibanding konsorsium 1 dan gabungan 1+2 (Tabel 4).

Tabel 4 Pengaruh pupuk hayati dan NPK terhadap jumah anakan padi gogo

\begin{tabular}{lcccc}
\hline \multicolumn{1}{c}{ Perlakuan } & \multicolumn{4}{c}{ Rerata jumlah anakan } \\
\cline { 2 - 5 } & $21 \mathrm{HST}$ & $28 \mathrm{HST}$ & $35 \mathrm{HST}$ & $42 \mathrm{HST}$ \\
\hline Pupuk hayati konsorsium & & & & \\
- tanpa pupuk hayati & $3,11 \mathrm{a}$ & $5,91 \mathrm{a}$ & $9,52 \mathrm{a}$ & $20,44 \mathrm{a}$ \\
- konsorsium 1 & $4,02 \mathrm{~b}$ & $9,33 \mathrm{~b}$ & $13,33 \mathrm{~b}$ & $25,61 \mathrm{~b}$ \\
- konsorsium 2 & $5,11 \mathrm{~b}$ & $11,19 \mathrm{~b}$ & $18,11 \mathrm{~b}$ & $29,65 \mathrm{~b}$ \\
- konsorsium 1+2 & $4,00 \mathrm{~b}$ & $8,28 \mathrm{~b}$ & $15,28 \mathrm{~b}$ & $27,91 \mathrm{~b}$ \\
Dosis Pupuk NPK & & & & \\
- 100\% & $3,66 \mathrm{a}$ & $8,36 \mathrm{a}$ & $13,66 \mathrm{a}$ & $27,91 \mathrm{a}$ \\
- 75\% & $4,19 \mathrm{a}$ & $8,89 \mathrm{a}$ & $13,94 \mathrm{a}$ & $25,69 \mathrm{a}$ \\
$-50 \%$ & $4,11 \mathrm{a}$ & $8,41 \mathrm{a}$ & $13,80 \mathrm{a}$ & $25,27 \mathrm{a}$ \\
$-25 \%$ & $4,27 \mathrm{a}$ & $9,05 \mathrm{a}$ & $14,83 \mathrm{a}$ & $24,74 \mathrm{a}$ \\
\hline
\end{tabular}

Keterangan : Nilai rata-rata yang diikuti dengan huruf yang sama tidak berbeda nyata menurut Uji Jarak Berganda Duncan pada taraf $5 \%$. 
Hal ini menunjukkan bahwa isolat BPF dan BPN yang terkandung dalam pupuk hayati ini mampu meningkatkan jumlah anakan padi gogo. Hal ini sejalan dengan hasil penelitian Biswakarma dkk. (2018) yang melaporkan bahwa aplikasi bakteri pelarut $\mathrm{P}$ mampu meningkatkan jumlah anakan padi.

\section{KESIMPULAN}

Aplikasi pupuk hayati konsorsium 1 (Pseudomonas mallei, P. cepacea, Aspegillus niger dan Penicillium, Azotobacter sp., Azospirilium), dan pupuk hayati konsorium 2 (Azotobacter chroococum, A. vilandii, Azospirilium, Pseudomonas cepaceae, Penicillium dan Acitenobacter) serta gabungan konsorsorsium 1 dan 2 mampu meningkatkan pertumbuhan padi gogo. Pengurangan pupuk NPK sampai dengan $25 \%$ pada tanaman padi gogo yang diberi pupuk hayati tidak mempengaruhi terhadap pertumbuhan tanaman. Dengan demikian pupuk hayati mampu meningkatkan efisiensi pupuk anorganik

\section{Ucapan Terima Kasih}

Terima kasih disampaikan kepada Kemenristekdikti yang telah mendanai penelitian Strategis Nasional Institusi tahun 2018 (16/UN6.E/LT/2018). Ucapan terima kasih disampaikan kepada Rektor UNPAD, Dekan Fakultas Pertanian dan Direktur Riset dan Pengadian Kepada Masyarakat UNPAD atas dukungan dan kerjasamanya. Ucapan terima kasih juga kami sampaikan kepada saudara Fahmi dan Yusuf yang telah banyak membantu pelaksanaan penelitian ini serta semua pihak yang telah membantu kelancaran penelitian ini.

\section{DAFTAR PUSTAKA}

Biswakarma, B., H. Verma and N.C. Sarkar. 2018. Effect of Phosphate Solubilizing Bacteria on Yield of Transplanted Rice under Lateritic Belt of West Bengal, India. International Journal of Current
Microbiology and Applied Sciences 7(2): 3192-3204

Fitriatin, B.N. , A. Yuniarti, and T. Turmuktini. 2014. The effect of phosphate solubilizing microbe producing growth regulators on soil phosphate, growth and yield of maize and fertilizer efficiency on Ultisol. Eurasian Journal of Soil Science. 3: $104-107$.

Fitriatin, B.N., P. Tamara, O. Mulyani, E.T. Sofyan, A.Yuniarti and T. Turmuktini. 2018. Influence of biofertilizer and humic acid on NPK content and yield of rice (Oryza sativa L.). International Journal of Agriculture, Environment and Bioresearch. 3: 20-27

Hardjowigeno, S. 2003. Ilmu Tanah. Akademika Pressindo, Jakarta.

Rao, S. 1994. Mikroorganisme Tanah dan Pertumbuhan Tanaman. Universitas Indonesia Press, Jakarta.

Saba, N., I. U. Awan, M.S. Baloch, I.H. Shah, M.A. Nadim, and J. Qadir. 2013. Improving synthetic fertilizer use efficiency through bio-fertilizer application in rice. Gomal University Journal of Research, 29(2): 32-28

Singh, T and S. S. Purohit. 2011. Biofertilizers Technology. New Delhi: Agrobios.

Simarmata, T., Tien Turmuktini, Mikeke R. Seiawati dan Y. Yuwariah. 2012. Teknologi Hemat Air dan PupukOrganik Berbasis Kompos Jerami dan Pupuk Bio untuk Mitigasi Gas Metan, Memulihkan Kesehatan Lahan Sawah, Meningkatkan Pertumbuhan dan Produktivitas BerbagaiVarietas Padi Sawah. Laporan Hibah Pasca.

Tan, K.H. 2008. Soils in the Humid Tropics and Monsoon Region of Indonesia. New York: CRC Press. 
Soilrens, Volume 16 No. 2, Juli - Desember 2018

Vahed, H.S., P. Shahinrokhsar and F. Heydarnezhad. 2012. Performance of phosphate solubilizing bacteria for improving growth and yield of rice (Oryza Sativa L.) in the presence of phosphorus fertilizer. Intl J Agri Crop Sci. 4 (17): 1228-1232. 